\title{
Sustainable Development Policy and Corporate Social Responsibility in Business Organisations in Nigeria
}

\author{
Abdul-Rahman A. Adegbite ${ }^{1}$, Sunday O. Amiolemen ${ }^{2}$, Idowu O. Ologeh ${ }^{2} \&$ I. O. Oyefuga ${ }^{2}$ \\ ${ }^{1}$ Africa Regional Centre for Space Science and Technology Education, Obafemi Awolowo University, Nigeria \\ ${ }^{2}$ National Centre for Technology Management, South-West Office, Lagos, Nigeria \\ Correspondence: Sunday O. Amiolemen, National Centre for Technology Management, South-West Office, 9 \\ Kofo Abayomi Victoria Island, Lagos, Nigeria. Tel: 234-703-387-0090. E-mail: samiolemen@gmail.com
}

Received: March 6, 2012 Accepted: May 14, 2012 Online Published: May 24, 2012

doi:10.5539/jsd.v5n6p83

URL: http://dx.doi.org/10.5539/jsd.v5n6p83

\begin{abstract}
Climate change which occurs as a result of natural and anthropogenic factor is majorly exacerbated by emission of green house gases, destruction of landscape greenery, injudicious disposal of waste and effluents emanating from industries. All these portend grave implications to environmental health and sustainability. This paper evaluates sustainable development practices and awareness in business organisations in Nigeria. It also assesses the commitment of firms to the three spheres of sustainable development principles - social, economic and environmental. The paper underscores the factors hampering sustainable development practices in business organisations, and recommends ways by which they can effectively play their roles towards achieving the national agenda for sustainable development.
\end{abstract}

Keywords: sustainable development, environmental health, business organizations, Nigeria, climate change

\section{Introduction}

The concept of sustainable development has been evolving and has received recognition in many organisations around the world. The Brundtland Report 1987 (World Commission on Environment and Development) promotes the principle of sustainable development because of urgent needs to check and manage environmental degradation, population growth, resource depletion, loss of biodiversity and poverty. The Brundtland Report recommends that Business enterprise should adopt sustainable development as a central guiding principle since the principle was developed to deal with environmental, social and economic issues facing the world. The Earth Summit in Rio 1992 officially marks the introduction of sustainable development in business to meet the challenges of the 21 st century. This led to formation of bodies like the World Business Council for Sustainable Development (WBCSD) and the Business Action for Sustainable Development responsible in promoting sustainable development in business communities amongst others. These bodies advocate for sustainable business culture in organisations and promote the integration of economic, social and environmental framework in their operations. The rapid adoption of sustainable business in many companies has provided opportunity to develop closer collaboration with government, communities and other stakeholders. Generally, it is believed that most firms in Nigeria have not set or implemented their sustainable vision towards proper management of the environment. This can obviously be linked to the seemingly stark indifference of the Nigerian government to implementing and enforcing environmental laws and regulations; poor understanding of environmental issues, and lack of commitment to protecting and managing the environment by firms and business organisations. The non-committal of business organisations towards environmental management is indicative of the non-employment or paucity of environmental managers/sustainable development experts, who are to oversee and advise business organisations accordingly. Interestingly, most firms in Nigeria use fuel/diesel generator to power their business operations because of irregular power supply without recourse to addressing the concomitant noise and air pollution resulting from it. Therefore, evaluating sustainable development in business organisation in Nigeria will contribute to knowledge, sustainability practices, and stimulate high standard of business development practices in the country.

Mullerat and Brennan (2005) explained that sustainable and socially responsible business organisations recognize the necessity to operate a green business agenda while accepting environmental stewardship as an indivisible whole of business operations. This acceptance includes a willingness both to operate transparently and to engage actively; seeking opportunities for improvement through the use of eco-efficient solutions by developing new 
technologies, employing life-cycle perspectives in resource and product stewardship, and positively addressing biological diversity. Organisations around the world that have incorporated sustainable practices to strengthen their organisations goals have no doubt, increased shareholders values and built better global market share and competitiveness. In essence such corporate organisations contribute to the economic development and international relevance of their host countries. Considering the recent involvement of business organisations of developed countries in environmental and social development of their host communities, many studies were carried out to assess various achievements made, and the management approaches adopted. Berhout, Leach and Scoones (2003) citing Stubbs (2000) observed that academic research on sustainable practices in business organisations do not appear to have significantly reduced the gap between environmental awareness and progress towards sustainable business practices. Nevertheless, they concluded that researches carried out over the last decade have contributed immensely to our understanding of the responses of individual business to external pressures, organisation learning, green purchasing, green technology development and environmental management system among others. To this extent the need to investigate employees of corporate organisations on their awareness and commitment to sustainable development principle, and implementation by business organisations in Nigeria is essential and timely.

\section{Literature Review}

John Elkington (1997) in his book "Cannibals with Forks" introduced a new paradigm to managing business in a sustainable way. He expounded the Triple Bottom Line concept, thus presenting a real image of what sustainable practices should be in the corporate social responsibility policy of every business organisation. He suggested that for businesses to be sustainable they must consider the triple bottom line of economic profit, environmental quality and social justice. He revealed that sustainable capitalism, with its emphasis on the triple bottom line performance of companies, industries, and economies present business corporations with more complex challenges which he called the 7-drivers.

Table 1. Seven sustainability revolutions (7-drivers)

\begin{tabular}{ccccc}
\hline Revolution & Focus & Old Paradigm & $\rightarrow$ & New Paradigm \\
\hline 1 & Markets & Compliance & $\rightarrow$ & Competition \\
2 & Values & Hard & $\rightarrow$ & Soft \\
3 & Transparency & Closed & $\rightarrow$ & Open \\
4 & Life-cycle technology & Product & $\rightarrow$ & Function \\
5 & Partnerships & Subversion & $\rightarrow$ & Symbiosis \\
6 & Time & Wider & $\rightarrow$ & Longer \\
7 & Corporate governance & Exclusive & $\rightarrow$ & Inclusive \\
\hline
\end{tabular}

Source: John Elkington, 1997.

\subsection{Sustainable Development and Corporate Social Responsibility}

It is of note that concept of sustainable development in many organisations has revolved around the John Elkington triple bottom line and the WBCSD eco-efficient concept creating an ideal balance between corporate objectives and sustainable development policy. Also many organisations have incorporated environmental management systems in their operations, and their sustainable development practices communalised in line with the concept of Corporate Social Responsibility (CSR). According to the European Commission's Directorate-General for Employment and Social Affairs (2002) in his presentation of a Green Paper titled "Promoting a European Framework for Corporate Social Responsibility". He defined Corporate Social Responsibility (CSR) as a concept whereby companies integrate social and environmental concerns in their business operations and in their interactions with stakeholders on a voluntary basis as they are increasingly aware that responsible business behaviour and ethics lead to sustainable business success. May et al. (2007) provide detailed evidence in the interrelationship between CSR and sustainable business in their book the "debate over Corporate Social Responsibility". According to them both concepts highlight the notion of balancing interests-economic versus social and environmental interests and the current versus future generation's interests. They however cited Foot and Ross (2004) argument that sustainability or sustainable business is a broader concept compared to CSR. 


\subsection{Sustainable Business and Environmental Management}

The International Organisation for Standardisation (ISO) 2004, states that organisations of all kinds are increasingly concerned with achieving and demonstrating sound environmental performance by controlling the impacts of their activities, products and services on the environment, consistent with their environmental policy and objectives. They do so in the context of increasingly stringent legislation, the development of economic policies and other measures that foster environmental protection, and concerns expressed by interested parties about environmental matters and sustainable development. This led the ISO to provide ISO 14001 which specifies requirements for an environmental management system to enable an organization develops and implements policies and objectives which take into account legal requirements and information about significant environmental aspects. It is intended to apply to all types and sizes of organisation and to accommodate diverse geographical, cultural and social conditions (ISO 2004).

The world Commission on Environment and Development in 1987 presented the United Nation's Brundtland Commission Report (Our Common Future) which defined Sustainable Development as the ability to meet the needs of the present without compromising the ability of future generations to meet their own needs. The report recommends that sustainable development principle should become a central guiding principle of United Nations, Governments, private institutions, and business enterprises. This is as a result of urgent need to control environmental degradations, population growth, poverty and economic development. Deloitte and Touche (1992) indicated that the concept of sustainable development requires organisations to develop a culture that emphasizes employee participation, continuous learning and improvement. An International survey of European companies once reported that over half of the companies surveyed invited direct suggestions from employees on environmental issues. About $80 \%$ of these companies have changed their products or processes as a result of the suggestions and participation of their employees. For instance HSBC bank indicated it manages the direct environmental impacts of the business by working to reduce energy and water use, waste and $\mathrm{CO}_{2}$ emissions. This is said to be achieved by improving the environmental performance of the Bank's operations and incorporating sustainability into purchasing decisions. HSBC became the first major bank to become carbon neutral in 2005 (HSBC, 2009). The Bank continued to maintain its carbon neutrality - meaning its worldwide operations contribute zero net carbon dioxide into the atmosphere by setting environmental targets.

According to United Nations Environmental Programme Finance Initiative (UNEP FI) over 170 financial institutions across the world with about 9\% from Africa region work with UNEP FI to promote linkages between the environment, sustainability and financial performance. UNEP FI carries out its mission to train, identify, promote and realise the adoption of best environmental and sustainability practice at all levels of financial institution operation (unepfi.org). The UNEP FI presently has four financial institutions as members in Nigeria; they include Access bank, Fidelity Bank, Guaranty Trust Bank (GTB) and Zenith Bank.

In its commitment to make business more sustainable, the 1992 Earth Summit in Rio endorsed eco-efficiency as the way forward for companies individually and collectively to contribute towards sustainable development. This is a management philosophy that encourages business to become more competitive, innovative and more environmentally responsible. Eco-efficiency embraces other concepts such as pollution prevention, waste reduction, waste minimization and clean (or cleaner) production.

The ability of organisations to innovate is combined with the firm's primary motivator-profitability. As such, energy efficiency, waste reduction and environmental design offer potential financial benefits to companies offering or practising sustainable development policies. In view of the huge benefit of sustainable development practices in business organisation; the role every staff plays within the organisation is important. Employees at every level should understand and contribute to the process of sustainable development right from production to the delivery chains of goods and services. Companies are duty bound to take full responsibility for all their products; hence the whole cycle of a product should be considered at all levels of decisions to adding values and reducing negative environmental impact. In light of the increasing engagements of business organisations to managing environmental issues (climate change, global warming, deforestation, resource depletion) around the world; it is necessary to clearly evaluate the environmental concerns of firms in Nigeria; even though majority of them claimed to have adopted the concept of sustainable development in the operations of their businesses.

\section{Methodology}

Structured questionnaires and guided interviews were used to gather information on sustainable development policy and corporate social responsibility in some business organisations in Nigeria, namely oil and gas, telecommunication and banking industry. A total of sixty-six questionnaires were randomly distributed among the management and staff of the selected business organisation. Fifty-one (51) questionnaires were retrieved with only 
forty-three (43) questionnaires counted valid for analysis. Twenty-four (24) questionnaires were retrieved from management and staff of selected banking organisations; twelve (12) questionnaires were retrieved from management and staff of selected telecommunication organisations; while seven (7) questionnaires were retrieved from management and staff of selected oil and gas firms. The responses were tabulated with the percentage of respondents taken.

\section{Results and Discussions}

Climate change occurs as a result of natural and anthropogenic factors. Long before the advent of industrial revolution till date, the diverse activities of human have increased the level of $\mathrm{CO}_{2}$ in the earth atmosphere by about $35 \%$. As such, a sustainable corporate behaviour that will promote environmental sustainability is essential. Table 2 shows that twenty-six (26) respondents accounting for sixty percent $(60 \%)$ of the total sampled employees accept that their organisations adopt the principle of sustainable development in their operations.

Table 2. Organisations/employees awareness of sustainable development principles

\begin{tabular}{cccc}
\hline & YES & NO & NOT SURE \\
\hline Organisation adopts the principle of sustainable development & $26(60 \%)$ & $15(35 \%)$ & $2(5 \%)$ \\
Organisation invests on community development/CSR & $32(75 \%)$ & $7(16 \%)$ & $4(9 \%)$ \\
Organisation is committed to health and safety of costumers and staff & $24(56 \%)$ & $6(14 \%)$ & $13(30 \%)$ \\
Organisation has policy on climate change & $16(37 \%)$ & $18(42 \%)$ & $9(21 \%)$ \\
\hline
\end{tabular}

Similarly, thirty-two respondents (32) representing seventy-five (75\%) percent of the sampled employees submitted that their organisations contribute to the development of the society and host community. Thirty-two (32) respondents representing seventy-five (75\%) percent of the sampled employees offered that their organisations contribute to the development of the society and host community. One can also infer that some oil and gas, telecommunication industries, few old generation banks and some new generation banks engage in corporate social responsibility that borders on social, economic and environmental goals as depicted in Figures $1,2 \& 3$. Based on the survey result, it will be appropriate to submit that major oil and gas industries, telecommunication industries, few old generation banks and many new generation banks in Nigeria fall within the compliance and efficiency phase. Nevertheless several factors have been identified to be responsible for poor implementation of sustainable development policies by business organisations in the country. These factors include insufficient employee awareness; inadequate knowledge base on sustainable businesses; lack of experts in the field of sustainable development in firms; corporate and individual indifference to environmental issues; and uncoordinated government policies.

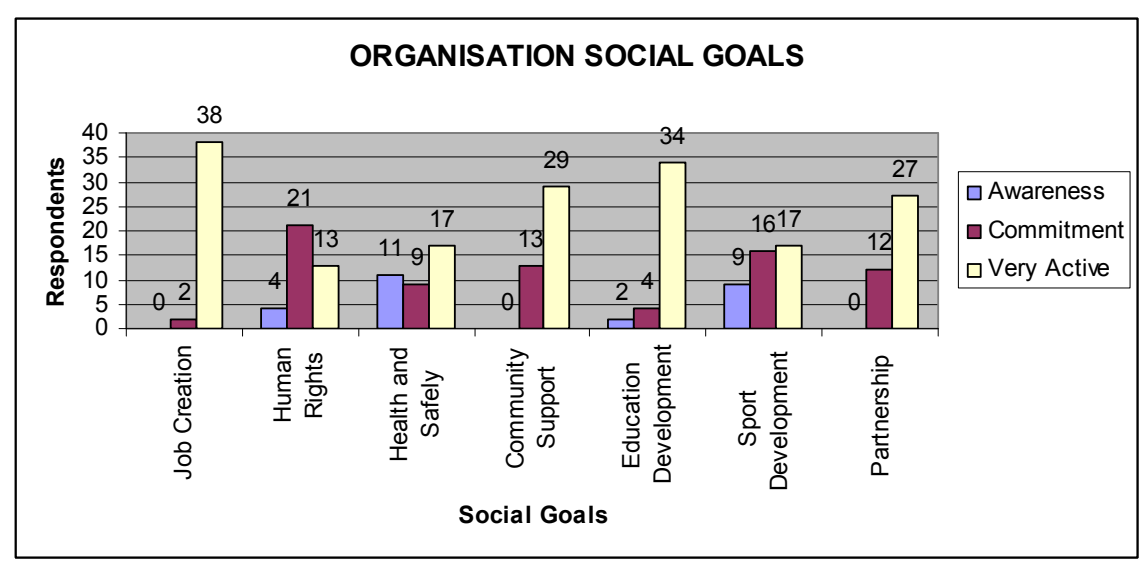

Figure 1. Trends of organisations' commitment to social goals 


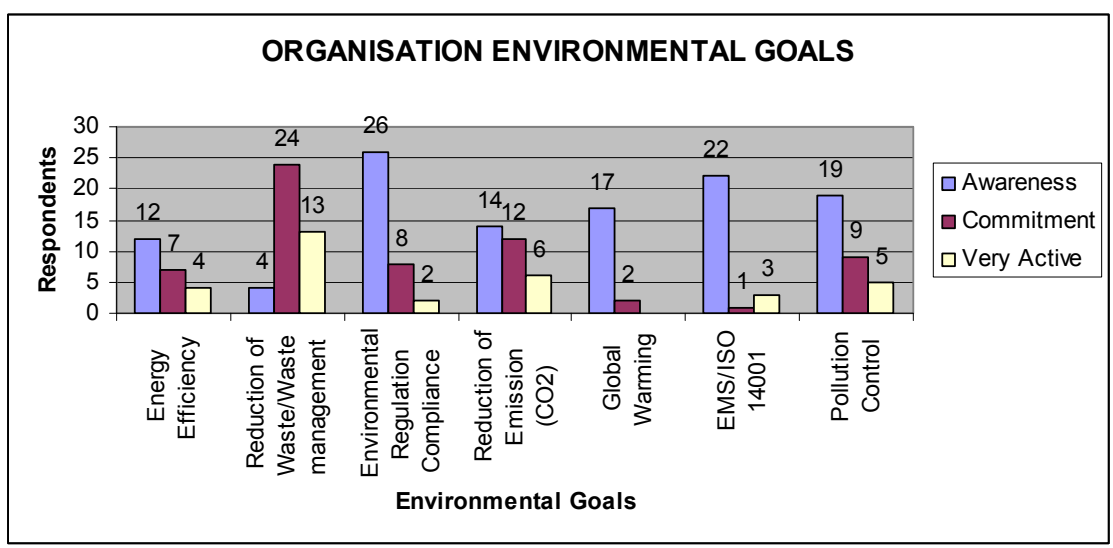

Figure 2. Trends of organisations' commitment to environmental goals

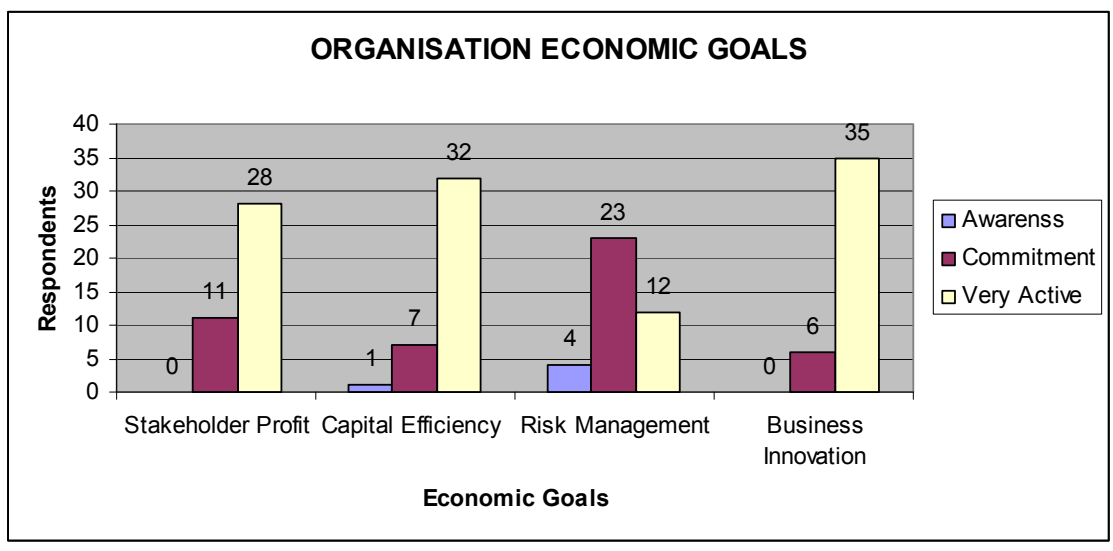

Figure 3. Trends of organisations' commitment to economic goals

\section{Conclusion and Recommendations}

The principle of sustainable development awareness by business organisations in Nigeria is examined. It was however discovered that the awareness and knowledge of employers on sustainable development, most especially on the protection of the environment is low. Nevertheless, majority of the organisations understudied have shown more commitment to socioeconomic development with less priority to environmental protection, control and management. The Nigerian government on her own part has not played the much needed role in stimulating firms to operate a high standard sustainable development policy, compared to the governments of United Kingdom, United States of America, South Africa and several others. Despite the fact that organisations awareness to sustainable development is relatively low, corporations in Nigeria have presently developed interest towards sustainable development as evident in planting a tree campaign of Lagos State. Many of these socio-economic and environmental responsibilities will go a long way in bringing the community closer to the organisation, thus gaining their respects, patronages and goodwill. It is however pertinent for Nigerian government as a matter of urgency to develop a well structured sustainable policy that will serve as templates and guide to business organisations in Nigeria. This step will definitely promote positive images of Nigerian businesses and services around the world. Finally, sustainable business agenda may be a way for corporations in Nigeria to maximise their profits if well conceptualised as a marketing/public relations strategy. The role of business organisations in nation building is immeasurable if the principle of sustainable development is adopted. To this extent, the recommendations outlined below are made to provide appropriate guide for corporations in Nigeria to be more committed to sustainable development principle in their business objectives.

- Organisational Commitment: Organisational commitment to sustainable development is essential, as it promotes good relationship and understanding between stakeholder (employer, employees, government and general public). Therefore, organisations in Nigeria should be more willing to put extra effort to implement policies that will promote sustainable business goals and values at every level in their operations. 
Organisation should be committed to the triple bottom line and eco-efficient concepts to establish a balance between their business objectives to achieve effective sustainable business framework.

- Continuous Improvements: Corporation management should endeavour to review and improve its sustainable goals to meeting the needs of present generation. This means business leaders must act professionally to meet everyday challenges and channelling resources to achieving high business standards around the world.

- Education and Training: Corporations must invest time and resource into sustainable business. The education and training of all stakeholders in relation to the dynamics of sustainable business is essential in raising the awareness of stakeholders and for improving organisation quality and performance.

- $\quad$ Research and Development: The major problem hindering most Nigerian firms to embrace the concept of sustainable development in business development is because they lack the technicalities and knowledge required to stimulate business growth and promote corporate brand within the framework of sustainable development. Therefore, there is need for firms and organisations to research on how they can make social and economic profit through their involvement in protecting and conserving the environment. In addition, firms should also focus on sustainable procurement and sales of product brands and services that are cost effective and environment friendly.

- Environmental Management: Business organisations in Nigeria need to take urgent steps towards the management of the environment because they generally lack interest in this direction. However, it is suggested that corporations in should endeavour to implement a well structured environmental management systems (EMS) as an operational tool to protect the environment.

- Partnership: It is very important for corporations in Nigeria to partner with similar business organisations in developed nations to seek information and technology transfer. They should also share human resources to promote sustainable development policy and to meeting global standards.

- Compliance with Legislation: There is need for business organisations in Nigeria to comply with legislation/regulations guiding their operations. For instance, the oil and gas industries should make necessary provision/actions to comply with Gas Re-Injection Act to prevent gas flaring in the Niger Delta region.

- $\quad$ Reporting and transparency: Organisations in Nigeria should recognise that one of the important ways to boost and inform the world about their sustainability achievements is for them to publish their sustainability reports. This type of reports should be produced from time to time to account for their sustainable development performance, and on decisions made to meeting issue arising from their sustainable development policy. The reports should be available to all stakeholders through communication media like internet, conferences/workshops, press releases and television programmes.

- Government involvement: To enable corporations attain efficiency and effectiveness towards a well implemented sustainable development policy. The Federal Government of Nigeria is expected to provide national strategies and indicators which will drive the nation's sustainable development policy to meeting international standard (agenda 21). Government should also establish agencies responsible for managing and coordinating sustainable development practices by business organisations. The government should be committed to providing effective legislations that will monitor and control organisations' impact on the environment. In addition, provides the needed infrastructures (good transportation system, electricity, health care, education, security) that will strengthen any effort made by business organisations towards sustainable development.

\section{References}

Agyemen, J., Bullard. D., \& Evans, B. (2003). Just sustainabilities: Development in an Unequal World. Published by Earthscan.

Berkhout, F., Leach, M., \& Scoones, I. (2003). Negotiating environmental change: new perspectives from social science. Cheltenham: Edward Elgar.

Brundtland, H. (1987). Our common future: World Commission on Environment and Development. Oxford University Press.

Deloitte, \& Touche. (1992). Business Strategy for Sustainable Development: Leadership and Accountability for the 90s. Published by International Institute for Sustainable Development in conjunction with the World Business Council for Sustainable Development. Retrieved April, 2011, from http://www.bsdglobal.com/pdf/business_strategy.pdf 
Dunphy, D., Griffiths, A., \& Benn, S. (2003). Organizational Change for Corporate Sustainability: A guide for leaders and change agents of the future. Published by Routledge.

Elkington, J. (1997). Cannibals with forks: the triple bottom line of 21 st century business. Published by Capstone.

European Commission's Directorate-General for Employment and Social Affairs. (2002). Corporate social responsibility: a business contribution to sustainable development. Published by Office for Official Publications of the European Communities. Retrieved April, 2009, from http://ec.europa.eu/employment_social/publications/2002/ke4402488_en.pd

HSBC. (2009). Sustainability Home page. Retrieved June, 2011, from http://www.hsbc.com/1/2/sustainability/environment

May, S., Cheney, G., \& Roper, J. (2007). The debate over corporate social responsibility. Published by Oxford University Press US.

UNEP FI. (no date). About United Nations Environment Programme Finance Initiative (UNEP FI). Retrieved August, 2011, from http://www.unepfi.org/about/index.hmtl

UN-DESA. (1999a). Economic Aspects of Sustainable Development in Nigeria: Agenda 21. Retrieved August, 2011, from http://www.un.org/esa/agenda21/natlinfo/countr/nigeria/eco.htm

World Business Council for Sustainable Development. (1996). Eco-efficient Leadership for Improved Economic and Environmental Performance. Geneva. 